French energy policy

\section{The great escape}

There were two striking omissions from the roster of nationalization proposals announced by the Prime Minister of France, M. Pierre Mauroy, recently Framatome and Novatome, the companies which between them account for almost the whole business of constructing conventional and fast breeder reactors in France. The exceptions are remarkable because the Socialist Party had announced before the election that all industries concerned with the nuclear fuel cycle would be nationalized.

M. Mauroy was, however, quite clear in what he said: eleven groups would be nationalized, not one more nor one less. The omission of the nuclear industry is another indication that the new government does not intend seriously to disturb France's growing lead in nuclear technology. Mauroy explained that the companies to be nationalized are included in his list not for doctrinal reasons but to improve their competitive performance as has been done with the car maker Renault. (In fact the new Minister for Industry, M. Pierre Dreyfus, was previously managing director of Renault, so his appointment has somewhat comforted industrial opinion.) Thus the immunity of the nuclear business amounts to a tacit recognition of its independent commerical success.

The grand debate on energy also begins to look less of a confrontation than a few weeks ago. It is expected now to take place in the National Assembly in November and instead of focusing on nuclear power it will look at all aspects of the energy question, a difficult matter in what will be a packed legislative session. Parliamentary and specialist groups have been set up to investigate separate issues.

Anticipating the debate, M. Mauroy has seen fit to announce the broad outlines of French energy policy. The two priorities will be to develop indigenous fossil fuel production, insofar as that is economic (taking account of world prices) and to pursue a significant nuclear programme.

Mauroy did not mention renewable sources or even conservation, and his remarks on fossil fuel production are taken to imply caution in the further development of France's costly coal compared with the cheaper Australian product. That leaves, of course, nuclear power as the central plank of his energy policy.

On this reading, the government must arrange that the November energy debate will lead to a vote to continue to build new pressurized water reactors. (New starts are temporarily suspended.) The construction of Superphenix, the commerical demonstration fast breeder reactor, continues, and a decision on a second one can be comfortably left for a while.

Robert Walgate
Mongolia's jubilee \section{Following the lamas}

The Mongolian People's Republic this month celebrates the diamond jubilee of its foundation on 11 July 1921 . Included, de facto, in the anniversary is the Mongolian Academy of Sciences, since although formally inaugurated only in May 1961, it originated, in the words of Dr B. Shirendyb, president of the academy, from "a small group of scientific workers" who banded together immediately after the establishment of the Republic to raise the scientific standards of the country.

Not that science had been entirely neglected in pre-revolutionary Mongolia. An astronomical observatory had been founded in Ugra (now Ulan Bator) in 1779, and a flourishing medical tradition was preserved in the lamaseries. Nevertheless, in the early years of the new state, the major task was the translation of basic scientific texts from Russian and other European languages. And before even this could be done a more fundamental problem had to be solved of replacing the picturesque but impractical traditional script by a modern alphabet.

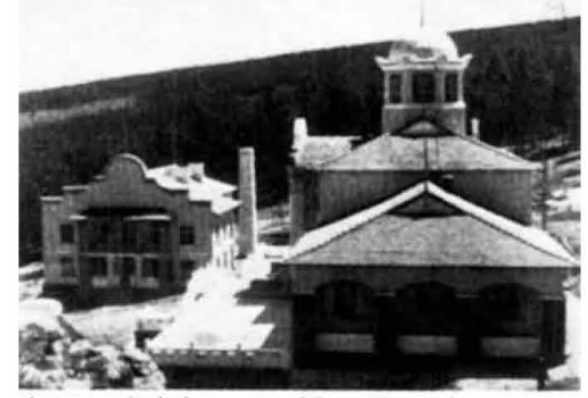

Astronomical observatory Mongolian style

Inevitably, present day research in Mongolia is largely directed towards the needs of the economy. During the past five years, the various institutes of the Academy of Sciences carried out 369 research projects, which should ultimately save the economy more than 108 million tugriks ( $£ 18$ million). Research included the use of methods of nuclear physics in surveying the country's deposits of copper, molybdenum and tungsten, mapping of seismic zones, the extraction of pharmaceuticals from traditional medicinal herbs, and the development of new strains of wheat and breeds of sheep.

International help has not been lacking. The plan to establish a 5 million hectare nature reserve in the Gobi Desert is receiving considerable assistance from the United Nations Environmental Programme, and Comecon countries have some 60 joint research projects in operation with Mongolia. One piece of research, not yet covered by a formal agreement but watched with considerable interest by Mongolian scientists, is the work of Dr Tibor Farkas at Szeged
(Hungary) on the biophysics and biochemistry of frost damage. The Mongolians hope that this work will result in the development of an anti-frost spray for spring wheat, which is at considerable risk in their harsh climate.

Among the facilities that Mongolia has to offer its international collaborators is the Gobi Desert - a valuable hunting ground for Comecon expeditions in search of fossils of dinosaurs and dinosaur eggs.

Vera Rich

\section{Belgian scientific institutions}

\section{Arresting decline}

\section{Brussels}

It has long been felt in Belgium that some of the country's most renowned scientific institutions are falling into decline. Disaffection is so great that last spring the staff of eight major institutions resorted to strikes to draw attention to their grievances. Now at last the government has decided to do something.

A committee of wise men has been given the task of finding ways to unravel the administrative snarls which are held responsible for the problems. The eight institutions under review are the Royal Library of Belgium, the National and Provincial Archives, the Royal Belgian Institute of Natural Sciences, the Royal Museum for Central Africa, the Royal Belgian Observatory, the Royal Belgian Meteorological Institute, the Belgian Institute of Aerospace and the National Centre for the Production and Study of Microbiological Substances.

The problems of these institutions are uniquely Belgian. When the constitution was revised in 1970, it was decided to keep them as national bodies. The conflict between the Flemish and Walloon (Frenchspeaking) communities in Belgium has led to a virtual duplication of all administrations and much else. The education system is completely divided along linguistic lines. As national bodies, the eight institutions in question fall foul of the system and do not benefit from the patronage of either the French or Flemish education ministers.

Every decision has also to be approved by three or four ministries and with a change of government every few months, the national institutions have found it very difficult to get anything done. Most of the directors of the institutions have left in disgust at the administrative confusion.

The committee is due to make its first report within the next three months, but the recommendations are bound to involve more drastic cures than simple administrative pruning. Some of the institutions with more active research departments are sure to be merged with universities. And the worrying size of Belgium's publicsector deficit may prompt the committee members to recommend that parts of the institutions should be axed completely.

Jasper Becker 